\title{
Paisagem e Geoconservação nos Territórios do Pampa Brasil-Uruguai - reflexões para uma política transfronteiriça
}

\author{
Landscape and Geoconservation in the Territories of the Pampa Brazil- \\ Uruguay - reflections to a cross-border policy
}

\author{
Adriano Severo Figueiró ' ; Jaciele Carine Sell "
}

\section{RESUMO}

A paisagem do Pampa apresenta um enorme desafio ao debate da conservação ambiental, já que os testemunhos dos processos pretéritos têm sido mantidos graças a condicionantes culturais de baixo impacto no tempo presente, sustentando uma complexidade paisagística única, decorrente desta simultaneidade do não contemporâneo. Não é por outro motivo que o Pampa brasileiro representa hoje o bioma com o mais baixo grau de proteção dentro do Sistema Nacional de Unidades de Conservação, com apenas 3,3\% da área total protegida (2,4\% em Unidades de uso sustentável e 0,9\% em Unidades de proteção integral). À luz das políticas públicas de conservação esta complexidade se amplia, na medida em que concebemos a existência de um único sistema paisagístico submetido a três diferentes marcos jurídicos dentro dos países que compartilham esta paisagem (Brasil, Uruguai e Argentina), o que abre espaço para atividades econômicas de grande escala que têm levado à rápida degradação e descaracterização das paisagens naturais destes territórios. Neste sentido, discutir alternativas de conservação ligadas ao geopatrimônio do Pampa, não apenas permite pensar a conservação desta paisagem para além do biótico, como também se garante a base de sustentação e proteção de ecossistemas muito antigos e biodiversos, que dependem da garantia das estruturas geológico-geomorfológicas da paisagem para continuarem a existir.

Palavras-chaves: Pampa Brasil-Uruguai; Geoconservação; Paisagem. 


\section{ABSTRACT}

The landscape of the Pampa presents a huge challenge to the environmental conservation debate, since the testimonies of the past processes have been maintained in function of cultural conditions to the low impact in the present time, sustaining a landscape complexity unique, resulting from this simultaneity of the noncontemporary. It is not for any other reason that the Brazilian Pampa today represent the lowest protected biome within the National System of Conservation Units, with only $3.3 \%$ of the protected area $(2.4 \%$ in Sustainable Use Units and $0.9 \%$ in Full Protection Units). Regarding of public conservation policies this complexity increases as we conceive of the existence of a single landscape system subject to three different legal frameworks within the countries that share this landscape (Brazil, Uruguay and Argentina), which makes way for large-scale economic activities that have led to the rapid degradation and decharacterization of the natural landscapes of these territories. In this sense, discussing conservation alternatives linked to the Pampa geoheritage not only allows us to think about the conservation of this landscape beyond the biotic elements, but also ensures the base of support and protection of very old and biodiverse ecosystems, which depend on the guarantee of geologicalgeomorphological structures of the landscape to continue to exist.

Keywords: Brazil-Uruguay Pampa; Geoheritage; Landscape.

\section{INTRODUÇÃO: A CARACTERIZAÇÃO DA PAISAGEM PAMPEANA COMO BIOREGIÃO}

A paisagem do Pampa se define a partir de duas características bastante demarcadas: de um lado, a grande sensibilidade ${ }^{1}$ que decorre do alto grau de complexidade na integração entre estruturas e processos naturais não contemporâneos que, todavia, coexistem simultaneamente no fenosistema pampeano atual (SUERTEGARAY e PIRES DA SILVA, 2009). Cercada regionalmente por relevos de maior elevação, esta paisagem topograficamente rebaixada recebe sedimentos e umidade proveniente tanto do complexo montanhoso da cordilheira andina a oeste, quanto do planalto meridional vulcânico brasileiro, a leste-nordeste.

\footnotetext{
${ }^{1}$ Utilizamos aqui o conceito de sensibilidade da paisagem tal como proposto por Thomas e Allison (1993), sendo um grau de probabilidade a mudanças estruturais como resposta a pressões externas capazes de alterar os níveis de conexão entre os elementos, rompendo a capacidade de resiliência do sistema e conduzindo a um novo patamar de equilíbrio termodinâmico.
} 
Estes sedimentos são carregados e distribuídos por uma densa rede hidrográfica representada principalmente pelos rios que compõe o baixo-médio curso da bacia platina, constituída pelas sub-bacias dos rios Paraná, Paraguai e Uruguai e por seus respectivos afluentes.

De outro lado, o crescimento acelerado de diversas ameaças externas, especialmente derivadas de uma economia regional baseada em commodities (FIGUEIRÓ, 2017; GUDYNAS e EVIA, 2000), o que nos obriga a pensar em estratégias que possam contribuir para a construção de uma política de conservação do patrimônio paisagístico frente a este modelo colonial de desenvolvimento que desconsidera e destrói aquilo que é singular e próprio de cada lugar.

Com pouco mais de $350.000 \mathrm{Km}^{2}$ distribuídos entre os territórios dos dois países (figura 1), a paisagem do Pampa Brasil-Uruguai se caracteriza pela presença de um ecossistema aberto, com pequenas variações topográficas e dominância herbáceo-arbustiva sobre solos com grandes limitações para o aproveitamento agrícola, sendo por isso marcado, desde o século XVIII, pela presença da pecuária extensiva em áreas de médias e grandes propriedades.

Longe dos impactos normalmente gerados pela introdução de espécies exóticas, a chegada dos bovinos nas paisagens pampeanas desencadeou a retomada de uma dinâmica ecológica interrompida quando do desaparecimento dos grandes pastadores sul-americanos ao final do Pleistoceno (ZARTH e GERHARDT, 2009). Prova disso é que a análise do fenosistema anterior à ocupação pecuária, demonstrava a dificuldade em descobrir "... uma só milha quadrada em que não encontrasse na paisagem um grupo de árvores ou uma parte florestal..." (LINDMAN e FERRI, 1974, p.25). Após a introdução generalizada da pecuária no Pampa, a paisagem foi transformada de forma significativa, mas no sentido do retorno a um metaestado do final do Pleistoceno, cuja estrutura fisionômica respondia a um ambiente mais seco. Brailovsky (2006), por exemplo, comentando acerca da grande presença da palmeira Jataí (Butia yatay) na paisagem da mesopotâmia pampeana, afirma: 
tempo, expande e limita o palmeiral: o fogo de origem antrópica proporciona a luz solar que as palmeiras necessitam em seus primeiros estágios de desenvolvimento, o gado come os frutos e dispersa e semeia as sementes, mas também come as pequenas palmeiras. Em síntese, uma relação complexa, completamente diferente da que se estabeleceria nos mesmos ecossistemas na ausência de práticas pecuaristas. (BRAILOVSKY, 2006, p.151).

Assim, estas duas condições anteriores se expressam e se interconectam na paisagem do Pampa: de um lado, uma formação herbáceo-arbustiva que responde aos climas secos do final do Pleistoceno, ao invés do clima úmido atual; de outro lado, a introdução e manutenção de uma pecuária extensiva desde o século XVIII, transformando radicalmente a diversidade e a fisionomia da vegetação que evoluía em direção às condições de maior umidade (BEHLING et al, 2009). Esta combinação particular nos mostra como a formação fisionômica do Bioma Pampa está indissociavelmente ligada à história dos diferentes grupos humanos que lá vivem por vários séculos.

Figura 1 - Mapa de localização do sistema paisagístico do Pampa nos territórios do Brasil e do Uruguai

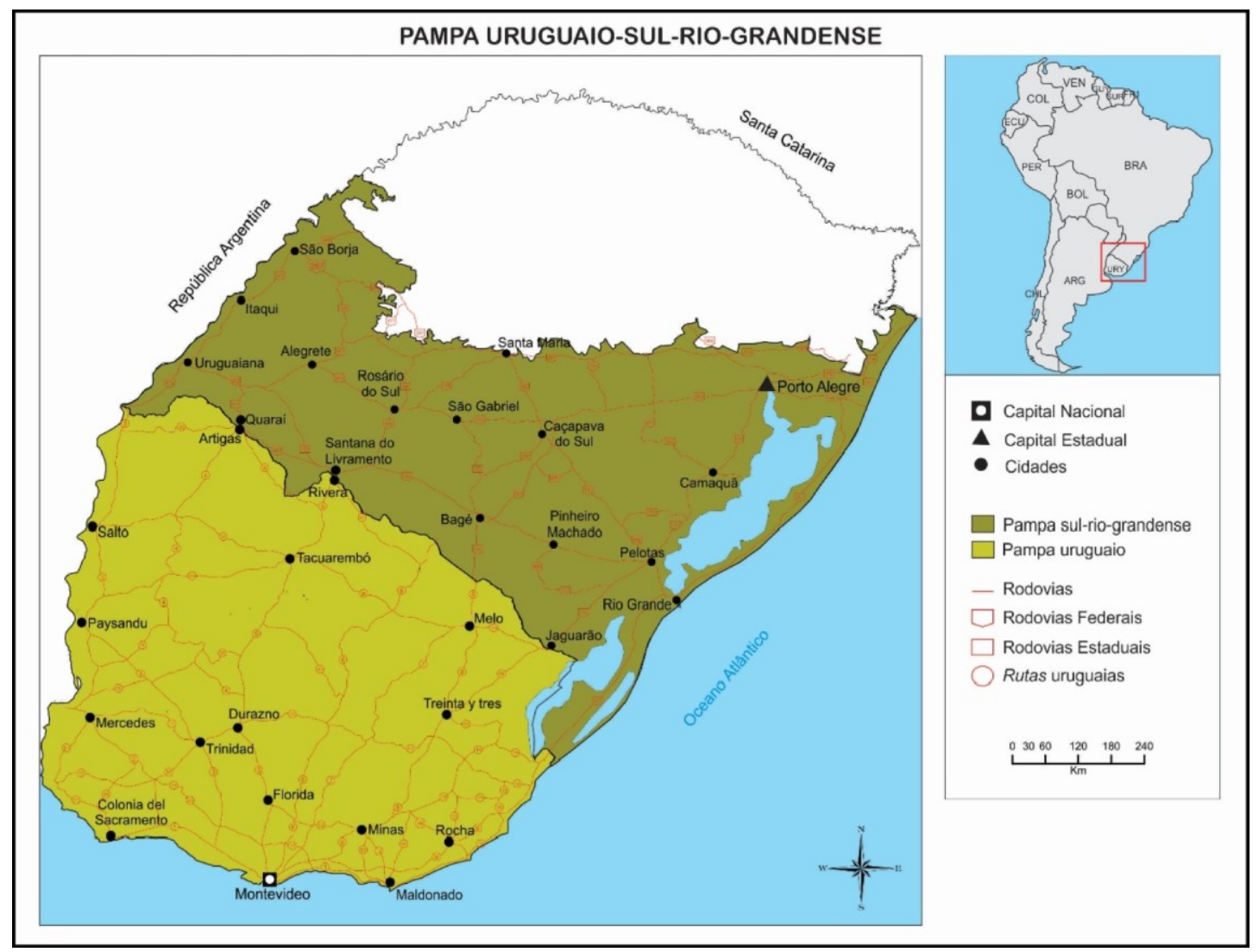

Fonte: Sell (2017). 
Tal constatação nos permite compreender a interconexão existente entre os diferentes elementos formadores da paisagem e, ao mesmo tempo, revela a fragilidade das abordagens ecológicas que ancoram o processo de conservação exclusivamente na defesa do seu patrimônio biótico, esquecendo que (...)

Não são apenas as espécies que estão desaparecendo; junto com elas e em nome de uma economia global que vê a natureza exclusivamente como fonte de recursos, desaparecem também diferentes formas de patrimônio que se forjaram em estreita ligação com estas comunidades bióticas ao longo da história: a geodiversidade e a diversidade cultural. (FIGUEIRÓ, 2012, p.67).

É exatamente devido a esta interconexão estruturante entre o natural e o cultural que temos defendido, na linha daquilo que já tem sido proposto por Gudynas (2002), que o Pampa não representa um simples bioma, mas sim uma bioregião, sendo esta entendida como um recorte territorial onde o conhecimento e o uso sustentável do patrimônio natural ao longo da história molda uma cultura própria e estabelece as bases para uma ocupação racional e sustentável da terra, baseada numa identidade entre a natureza e a sociedade que dela usufrui e com a qual interage. Um conceito ainda mais preciso é utilizado por Miller (apud CTI, 2000), ao definir uma bioregião como sendo (...)

(...) um território de água e solo cujos limites são definidos pelos limites geográficos das comunidades humanas e sistemas ecológicos. Tal área deve ser suficientemente ampla para manter a integridade das comunidades biológicas, habitats e ecossistemas da região; sustentar processos ecológicos essenciais, tais como os ciclos de nutrientes e resíduos, migração e fluxos; satisfazer as necessidades de território para espécies-chave; e incluir as comunidades humanas no manejo, uso e compreensão dos recursos biológicos. Deve ser suficientemente pequena para que os residentes locais a considerem seu lar. (CTI, 2000, p.18).

Em que pese o fato das relações ecológicas e, em especial, a sua estrutura vegetal resultante, jogar um papel decisivo na delimitação de uma bioregião, parecenos bastante evidente que ela não se dissocia da espacialidade daquelas comunidades que a usam como suporte biofísico de sustentação do seu modelo local de desenvolvimento. Tal como afirmam Berg e Dasmann (2003), “uma bioregião pode ser determinada inicialmente pelo uso da climatologia, fisiografia, geografia das plantas e animais, história natural e outras ciências descritivas da natureza. Os limites finais da 
bioregião, todavia, são melhor descritos pela população que tem vivido dentro dela" (p.232).

A abordagem bioregional representa um desafio não apenas para a gestão do território, que condiciona o processo de ordenamento e o seu modelo de desenvolvimento ao potencial ecológico fornecido pela paisagem; mas é um desafio epistemológico também para a própria Geografia, uma vez que a bioregião representa, antes de mais nada, uma resignificação do conceito geográfico de região, unificando sob a mesma estrutura espacial os olhares do território, da paisagem e do lugar. A bioregião não é portanto, apenas uma "região de vivência" (FONSECA, 1999), calcada nos elos de afetividade entre os seres humanos e o seu local de vida (BERNÁLDEZ, 1985); é um espaço geográfico onde o desenvolvimento econômico e social se dá em estreita ligação com o potencial ecológico ofertado pela natureza, reivindicando novos olhares conceituais e metodológicos para tratar a questão das diversidades paisagísticas, tendo por base as múltiplas determinações surgidas da complexidade das relações em tela e sua importância para a construção de um outro panorama de futuro para o planeta.

Em outras palavras, é um território que alicerça fortemente seu modelo desenvolvimentista no caráter regional, definido a partir de sua profunda identidade paisagístico-cultural. Este intercruzamento de conceitos rejeita o cartesianismo epistemológico de conceitos estanques a fim de estabelecer uma base material de ordenamento e gestão sustentável que tenha por princípio a conservação do patrimônio natural e seus serviços (LIPSCHUTZ, 2005) e, por conseguinte, da própria cultura associada a este patrimônio. Novamente aqui são Berg e Dasmann (op.cit.) que afirmam que uma bioregião "refere-se tanto a um espaço geográfico definido como a um território de consciência" (p.233), ou seja, quando falamos de bioregião, estamos falando ao mesmo tempo de um lugar e das ideias de como viver naquele lugar e a partir dele. Nas palavras de Menegat (2008), portasse uma impressão digital ou um DNA que Ihe fossem únicos. Porém, diferentemente dos genes dos ancestrais, os "genes do lugar" não ficam automaticamente registrados no organismo. Mas ficam impregnados, desde 
que nascemos, em nosso espírito e cultura de modo indissociável. Seja a língua, o sotaque, a comida, os jogos, a religião, tudo está profundamente influenciado pela paisagem, onde a cultura vai sendo cotidianamente construída. (MENEGAT, 2008, p.01).

Essa perspectiva não nos remete a uma mera resposta adaptativa de uma determinada sociedade ao seu ambiente, mas sim a um processo sistemático de coevolução social e ecológica (NORGAARD,1994), envolvendo a apropriação (material e cultural) e transformação da natureza pela sociedade a partir de um processo histórico de dupla determinação, ao qual González de Molina e Toledo (2011) definem como "metabolismo social".

O estudo da trama metabólica que se desenvolve na escala local desafia a constituição de uma unidade complexa de análise do bioregionalismo, cujas articulações permitem compreender dinâmicas territoriais derivadas de sinergias multiescalares (TOLEDO, 2013) que normalmente ficam ausentes dos estudos humanísticos e segmentados da paisagem enquanto sentido de lugar. Com isso, Alexander (1996) aponta o bioregionalismo como a "política do lugar", ultrapassando a simples perspectiva humanística de subjetividade historicamente associada ao conceito de lugar para ancorar-se na compreensão e defesa de um "patrimônio biocultural", tal como expressa Córdova (2013):

Se entendemos a cultura (...) como um conjunto simbólico que normatiza e molda o comportamento das sociedades e dos indivíduos, esta se localiza primeiramente nos terrenos do pensamento (o intangível) e se expressa, como conteúdo, na conduta e nos bens naturais e materiais que produz uma sociedade (o tangível), que são elementos básicos do que chamamos patrimônio biocultural, que dão continuidade histórica, ou seja, identidade. (CÓRDOVA, 2013, p.18)

Perceba-se a importância que assume no contexto do bioregionalismo o conceito de patrimônio, já que a adoção de um novo olhar sobre o território e seu processo de desenvolvimento deve nos permitir abandonar a perspectiva economicista de um mero e inesgotável "estoque de recursos" a ser explorado; esta concepção, por sua vez, teve sua elaboração conceitual por muitos anos projetada na ideia de um "capital natural" (STERN, 1997), cuja extração estaria, supostamente, ligada às melhorias dos níveis de desenvolvimento e conforto da sociedade. 
A substituição do conceito de "capital natural pelo de "patrimônio natural" no processo de ordenamento e gestão do território coloca em evidência duas ideiasforça extremamente importantes. De um lado, a ideia de patrimônio representa uma relação discursiva de ligação da natureza com as práticas sociais (SCIFONI, 2008), envolvendo uma "herança" geracional que, para ser transmitida, precisa ser usada de forma adequada e conservada. O patrimônio biológico stricto senso, o patrimônio biocultural e o geopatrimônio, são dimensões paisagísticas que passam a representar a base do processo de uma exploração sustentável do território de uma bioregião (figura 2), ao mesmo tempo em que representam a herança a ser conservada e a garantia de manutenção deste desenvolvimento a longo prazo.

Figura 2 - Representação esquemática da paisagem geo-bio-cultural, na interface dos processos coadaptativos entre a sociedade e a natureza em diferentes escalas de espaço e de tempo

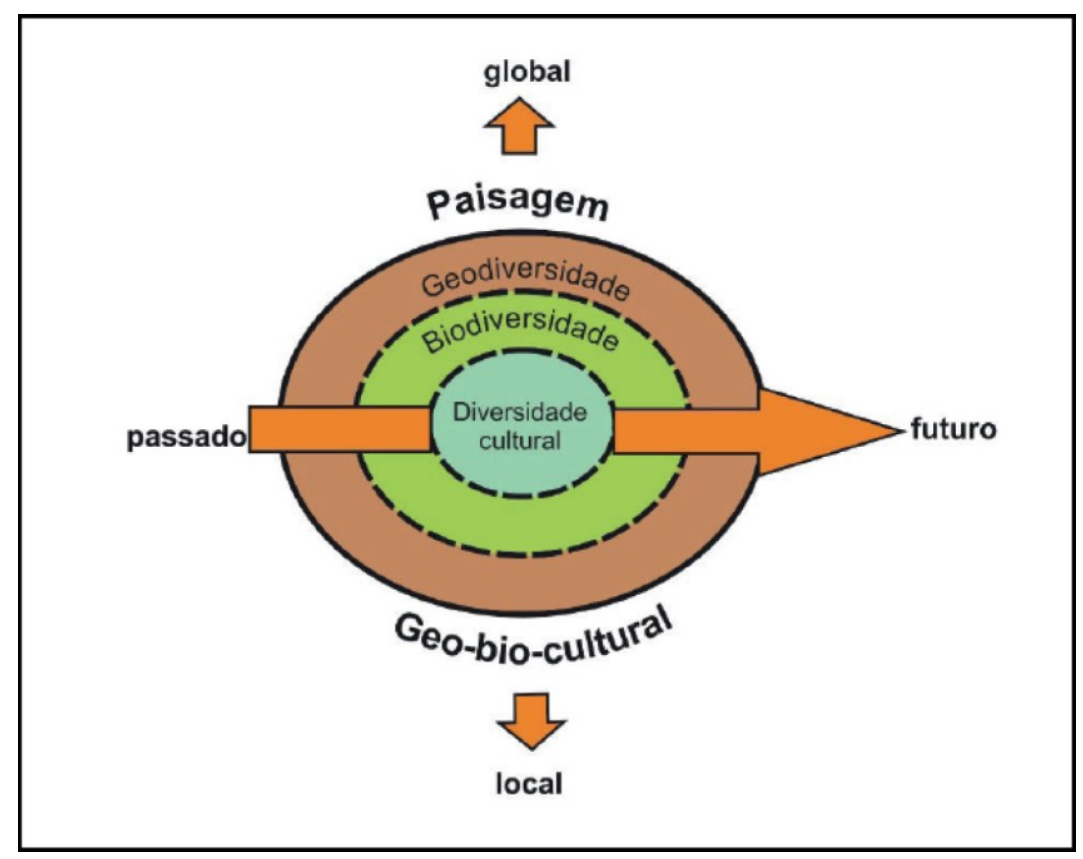

Fonte: Figueiró (2018).

Este modelo amplia a perspectiva das paisagens bio-culturais de Hong (2014), abrindo espaço para que possamos pensar em paisagens efetivamente geo-bioculturais, como resultante histórica do processo de domesticação da natureza pela 
cultura e da adaptação/domesticação da cultura pela diversidade da natureza. A paisagem, nestas condições, assume uma centralidade na interpretação das culturas, conectando a partir de uma perspectiva integrativa o passado, o presente e o futuro, numa relação dialógica entre o global e o local, o quê, no caso do Pampa, nos permite reconceituar o próprio território, não apenas pelas suas delimitações geográficas, mas "a partir dos agenciamentos de relações que se estabelecem entre paisagens, mulheres, homens, animais, ofícios e utensílios, na configuração de um modo de vida 'campeiro"' (RIETH, 2013, p.6).

De outra parte, a ideia de patrimônio incorpora múltiplos processos de valorização da natureza, onde o valor econômico é apenas mais uma forma entre outras (cultural, científica, estética, religiosa, ecológica, etc.). No momento em que o patrimônio perde o estatuto quase que exclusivo da monumentalidade e ganha também a dimensão da experiência pessoal e coletiva de diferentes grupos sociais, " $a$ identificação dos valores do bem a preservar remete (...) a um outro tipo de abordagem que leva em conta a relação dos grupos com o lugar, as práticas sócio-espaciais e não simplesmente o discurso técnico advindo da ciência ecológica" (SCIFONE, 2008, p.28). Assim, a paisagem não é apenas um suporte ao processo produtivo, mas um espaço de significações que nos informa sobre a evolução das dinâmicas da natureza ao longo do tempo e sobre como os seres humanos viveram, vivem e poderão viver naquele lugar, extraindo seu melhor potencial e respeitando seus limites de resiliência.

Diante do exposto, é central para que se possa rediscutir o processo de desenvolvimento e as alternativas de futuro para o território, que sejamos capazes de superar a visão do Pampa como um simples recorte ecológico associado a um bioma, para que passemos a considera-lo como uma bioregião, que apresenta uma clara identidade ecológica, cultural e produtiva derivada de um lento metabolismo socioambiental evoluído ao longo dos últimos dois séculos de história da relação sociedade-natureza.

A identidade paisagística desta bioregião já se expressa desde o seu nome ("Pampa"), derivado de um vocábulo Quichua que significa "grande planície", nome 
este atribuído pelos espanhóis que lá chegaram no século XVI, provenientes dos altiplanos bolivianos de exploração mineira (BRAILOVSKY, 2006). As superfícies aplainadas desta imensa área do Pampa, com aproximadamente 60 milhões de hectares e altitudes quase sempre inferiores a 300 metros e entrecortadas por pequenas depressões interfluviais que dão origem às formas de "coxilhas", criam uma identidade paisagística única a esta bioregião, tradicionalmente ocupada por formas extensivas de exploração pecuária. Ao mesmo tempo, o Pampa possui antecedentes históricos de ocupação que estreitam os vínculos culturais entre seus habitantes nos quatro países envolvidos por esta bioregião (GUDYNAS, 2002).

Em que pese a grande unidade paisagística e cultural, a bioregião do Pampa apresenta importantes heterogeneidades ecológicas internas que, se bem não

destroem a unidade bioregional, contribuem para aumentar sua diversidade e complexidade patrimonial naquilo que se refere às potencialidades de uso e necessidades de conservação. Decorre daí a necessidade de um maior detalhamento das ecoprovíncias que formam a ecoregião do Pampa Uruguaio-sul-rio-grandense, objeto deste artigo e uma das ecoregiões que formam a bioregião do Pampa.

\section{ECOPROVÍNCIAS DO PAMPA URUGUAIO-SUL-RIO-GRANDENSE: DIVERSIDADES NA UNIDADE}

Dentro de uma mesma bioregião, Olson et. al. (2001) propõem a delimitação de ecorregiões como a expressão da variabilidade paisagística naquilo que se refere às associações de espécies e a história geológica sobre a distribuição de plantas e animais. Assim, a ecorregião passa a ser definida como uma grande unidade de terra ou água que contém uma composição geograficamente distinta de espécies, comunidades naturais e condições naturais (BAILEY, 2002). Dentro da bioregião do Pampa, a ecoregião do Pampa Uruguaio-sul-rio-grandense, tradicionalmente denominada de "Savana Uruguaia" (HASENACK et al, 2010), compreende uma paisagem com predominância de planícies e sistemas serranos de baixa altitude em 
clima sub-tropical úmido, com pleno domínio de gramíneas mesófilas subtropicais (Andropogoneas e Paniceas) e solos mais rasos que a ecoregião do Pampa Úmido (na Argentina).

Figura 3 - Classificação dos sistemas ecológicos proposta por Hasenack et al (2010) para a ecoregião do Pampa Uruguaio-sul-rio-grandense

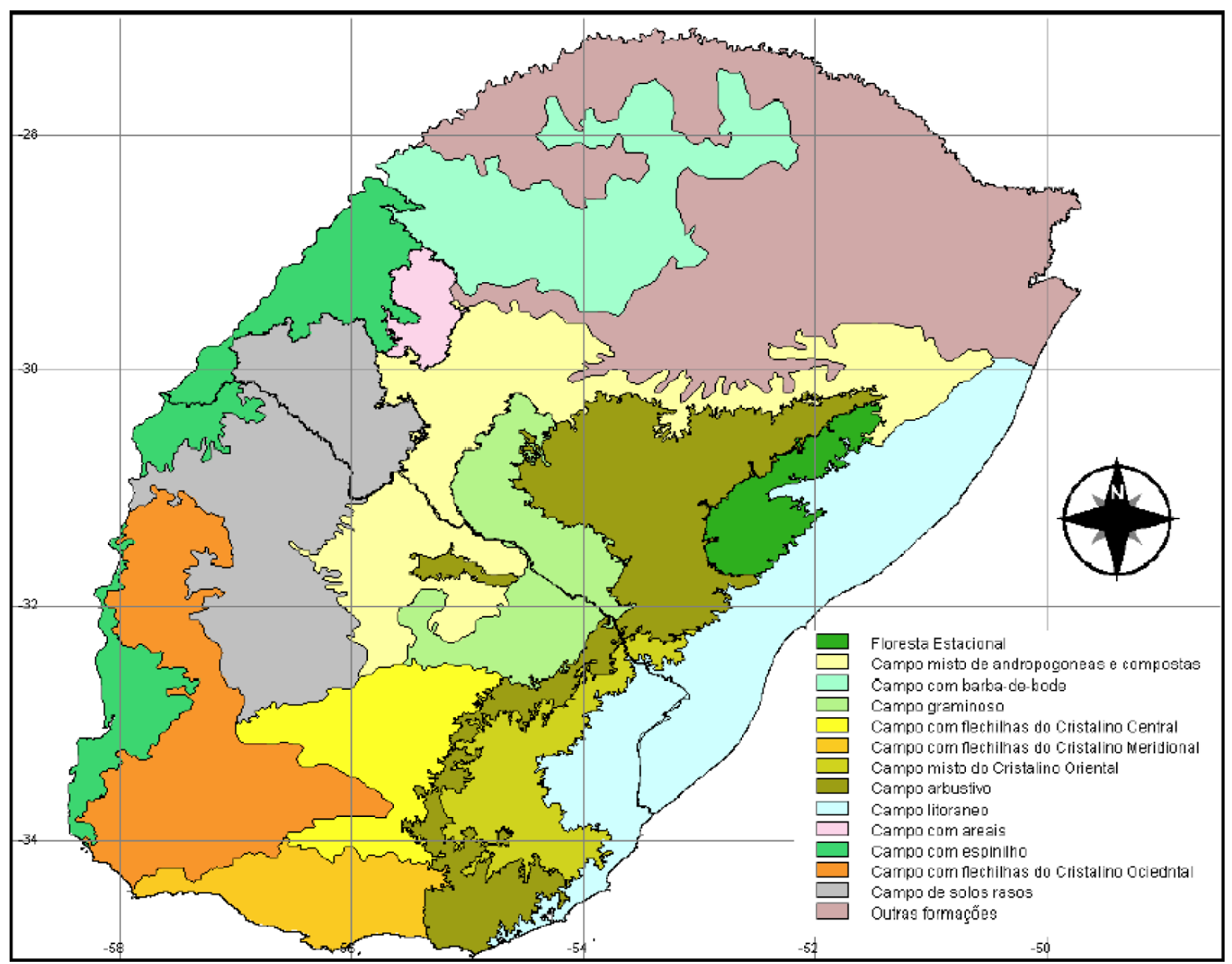

Fonte: Hasenack et al (2010).

Cabe ressaltar que Hasenack et al. (2010) e Boldrini et al. (2010), com base em características fisionômicas e de composição florística, subdividem a área de abrangência da ecoregião do Pampa Uruguaio-sul-rio-grandense em uma série de sistemas ecológicos (figura 3), demonstrando apenas uma das facetas da heterogeneidade da paisagem analisada. No entanto, além da descrição e regionalização tomando por base as formações vegetais, é preciso também aportar uma série de subsídios de geodiversidade e de evolução geológica que, ao se 
somarem às heterogeneidades fisionômicas, florísticas, culturais, sociais e econômicas irão auxiliar no sentido de uma nova regionalização ambiental e paisagística para essa região. Pretende-se, com isso, que futuras iniciativas e estratégias de conservação da natureza levem em consideração, também, as heterogeneidades geológico-geomorfológicas e as características que elas emprestam ao Pampa uruguaio-sul-rio-grandense.

Figura 4 - Proposta de regionalização das Ecoprovíncias do Pampa Uruguaio Sul-RioGrandense com base na geodiversidade e sua influência sobre os aspectos ecológicos e paisagísticos

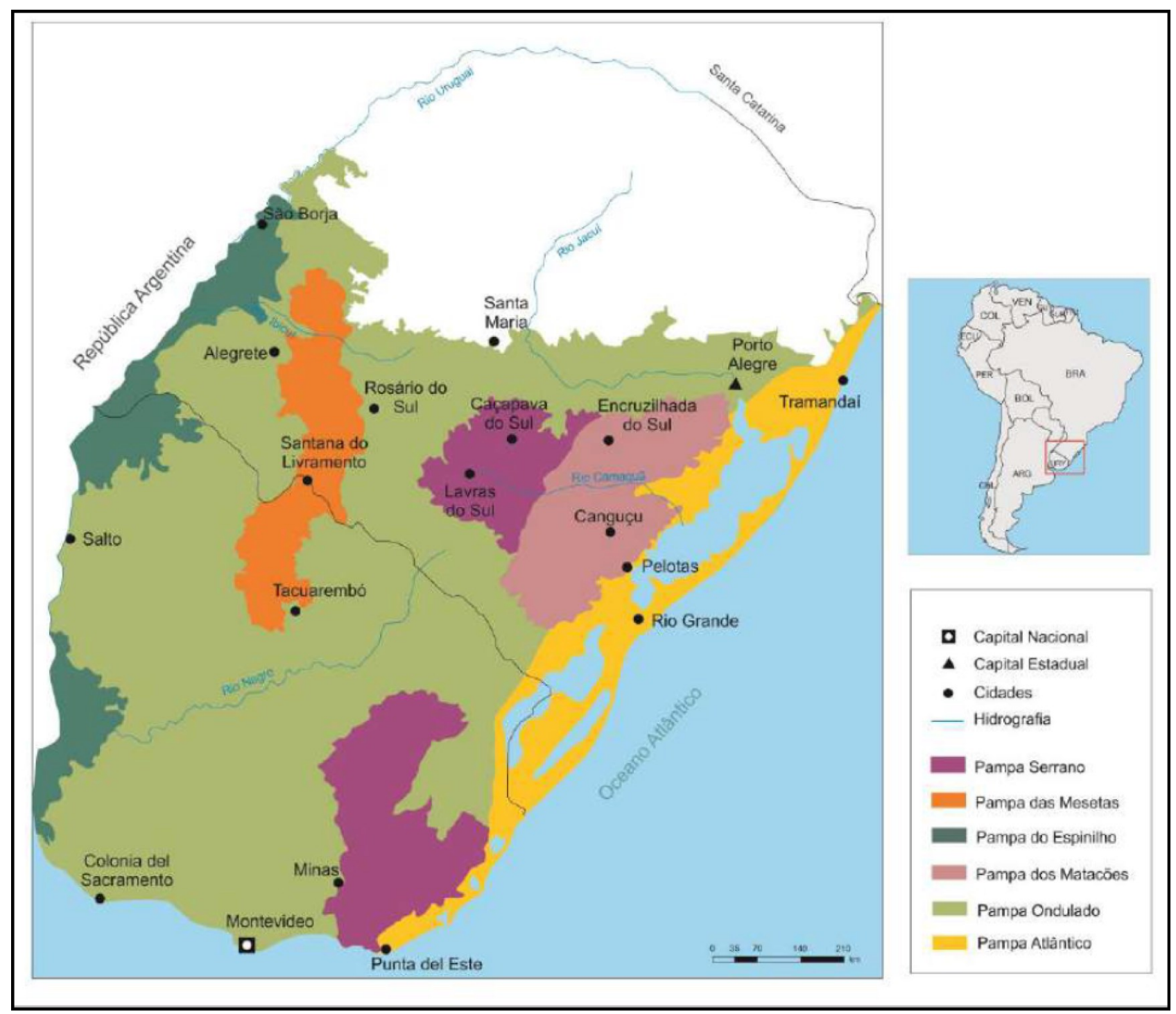

Fonte: Sell (2017). 
A geodiversidade, interpretada como a diversidade geológica, geomorfológica, edáfica e de recursos hídricos de uma determinada região ou território, possui significativa influência sobre a distribuição de formações vegetais e ecossistemas, bem como sobre a estruturação e manutenção de habitats para uma série de espécies de fauna e flora, inclusive no condicionamento dos endemismos. Adicionalmente, a geodiversidade influencia e, em certos casos, condiciona, os padrões de ocupação humana, inclusive impondo limites a essa, como nas áreas de alta declividade, suscetíveis a movimentos de massa, e nas áreas marginais a cursos d'água, suscetíveis a inundações. Ainda no que se refere à sociedade, a geodiversidade pode inspirar os costumes, as lendas e as tradições, além de fornecer o material para as construções históricas e determinar as vocações econômicas das comunidades, suas culturas agrícolas, rebanhos e bens minerais.

Diante disso, se optou em utilizar a geodiversidade como critério balizador para a proposição da regionalização desta ecorregião em seis ecoprovíncias distintas (figura 4), tomando por base o mapa da geodiversidade do Rio Grande do Sul (CPRM, 2009) e o mapa geológico do Uruguai (DINAMIGE, 1985), além de inúmeras publicações com sínteses regionais de geologia (BOSSI e NAVARRO, 1991; CHEMALE Jr., 2000; HARTMANN et al., 2000), meio ambiente (ACHKAR et al., 2012; GUDYNAS e EVIA, 2000; SEMA, 2010; MMA, 2000 e 2000; PILLAR, 2009) e fisionomia vegetal (HASENACK et al., 2010 e BOLDRINI et al., 2010).

\subsection{O Pampa dos Matacões}

Esta paisagem de cerros e planaltos graníticos com floresta estacional se estende como uma faixa de cerca de 300 quilômetros de extensão, com orientação NE-SW, desde os municípios de Herval e Arroio Grande, no extremo sul gaúcho, até Encruzilhada do Sul e Porto Alegre, em sua terminação norte/nordeste. Essa região possui como substrato rochoso uma série de corpos ígneos plutônicos, de diferentes dimensões, compostos por granitos e granodioritos diversos, reunidos sob a designação de Batólito Pelotas (PHILLIP et al., 2000). Essas unidades ígneas, formadas entre 630 e 550 milhões de anos, registram as raízes de uma antiga cadeia de 
montanhas que se estendia do sul do Uruguai até o norte do litoral catarinense, produzida pela colisão entre dois continentes ainda mais antigos (os crátons La Plata e Kalahari). Durante os processos de soerguimento relacionados à quebra de Gondwana e à abertura do Oceano Atlântico sul, estes corpos graníticos passaram a ser exumados e erodidos.

A relativa homogeneidade do substrato, somada ao caráter relativamente recente do soerguimento Cretáceo e da consequente exposição dessas rochas, faz com que toda essa região seja uma área mais elevada e plana, chegando a 500 metros de altitude, com grande destaque na paisagem que se abre a miradouros, especialmente ao longo das BR-392 e BR-471, que atravessam esta ecoprovíncia.

As rochas graníticas dessa região afloram na forma de grandes concentrações de matacões arredondados, entremeados de floresta, como no Parque Estadual do Podocarpus, em Encruzilhada do Sul, ou onde há presença do gado com pastagens nativas.

\subsection{O Pampa Atlântico}

Esta ecoprovíncia constitui-se na porção mais baixa e plana do Pampa, coincidindo com a Planície Costeira do Rio Grande do Sul (TOMAZELLI e VILLWOCK, 2000) e sua continuidade em território uruguaio. Esta unidade paisagística é a mais jovem do Pampa, tendo se formado ao longo dos últimos 400 mil anos como resposta aos sucessivos sistemas laguna-barreira desencadeados pela alternância de períodos glaciais (secos) e interglaciais (úmidos). Neste sistema, as lagunas, alimentadas nos períodos de maior umidade, são protegidas da ação do mar por uma barreira arenosa de depósitos de praia e dunas eólicas frontais, que se intensificam nos períodos de menor umidade. A barreira atual, materializada pelas praias arenosas gaúchas e uruguaias, protege uma série de corpos d'água interiores, como a Laguna de Tramandaí, a Laguna dos Patos, a Lagoa Mirim (ou Laguna Merín), a Laguna Negra, a Laguna de Castillos e a Laguna de Rocha, as quais são responsáveis pela garantia de habitat para uma riquíssima biodiversidade, especialmente associada à avifauna. O substrato dessa região é dominantemente arenoso, com algumas camadas mais ricas 
em matéria orgânica, como no caso dos depósitos de turfas. A porção arenosa é muito rica em quartzo, o que diminui drasticamente a fertilidade da maior parte dos solos. Esses fatores contribuem para que a vegetação seja apenas rasteira, com capões esparsos de mata paludosa e vegetação de restinga, com presença de figueiras do gênero Ficus e grandes extensões de palmares da palmeira butiá (Butia capitata).

Os banhados (áreas úmidas) são muito comuns nesta área, uma vez que o lençol freático está sempre muito próximo à superfície, aflorando em muitos pontos, sendo a mais extensa dessas áreas o banhado do Taim.

Em algumas porções desta ecoprovíncia, registram-se elevações isoladas em meio à planície costeira, formadas por corpos graníticos pertencentes ao Batólito Pelotas. Isso inclui costões rochosos junto ao mar, como a Punta del Diablo e o Cabo Polonio no Uruguai, e aquelas elevações mais interiores onde foram construídas as fortificações de San Miguel e Santa Teresa, que hoje constituem atrações turísticas de alto nível e de grande afluxo de visitantes.

\subsection{O Pampa Serrano}

As serras e cerros cristalinos com mosaicos de campo-floresta e formações arbustivas do "Pampa Serrano" representam a ecoprovíncia de maior diversidade paisagística do Pampa Brasil-Uruguai, e ocorre de forma descontínua em duas áreas distintas: (a) uma na porção ocidental do Escudo Sul-riograndense, englobando principalmente os municípios de Caçapava do Sul, Lavras do Sul e Santana da Boa Vista, na região do Alto Camaquã; e (b) entre os departamentos de Rocha, Maldonado e Lavalleja, no leste/sudeste do Uruguai. A mais importante característica física, compartilhada por ambas as áreas, como apontam Sell et al. (2015), é a alta geodiversidade: rochas metamórficas, como xistos, quartzitos, filitos, anfibolitos, gnaisses e mármores, com muitas estruturas deformacionais, encontram-se intrudidas por corpos graníticos isolados (plútons como os de Caçapava, Lavras, Jaguari, Capané, Carapé e Aiguá) e recobertas por sucessões sedimentares antigas 
(como as Guaritas de Caçapava do Sul) e rochas vulcânicas de diversas composições e idades (BORBA et al., 2013; PRECIOZZI et al., 1993).

Essa significativa geodiversidade, derivada de rochas de resistência variável ao intemperismo químico associadas aos soerguimentos ocorridos ao longo do Fanerozóico, levaram à formação de um relevo irregular, com cerros e serras de forte declividade. Soma-se a isso o fato de que os solos desenvolvidos sobre essas rochas são muito diversificados, desde ausentes ou muito delgados, sobre granitos, quartzitos ou arenitos, até solos profundos e bem estruturados, sobre as rochas vulcânicas ou metamórficas mais ricas em minerais ferromagnesianos. Por isso, nas Sierras de Rocha, nas Sierras de Minas ou nas serras que compõem a parte mais alta da bacia hidrográfica do rio Camaquã, é comum de se observarem, a poucos quilômetros de distância, cerros com grandes matacões graníticos arredondados, vales fluviais de solo fértil, cristas de quartzito ou xisto, cerros vulcânicos com disjunções colunares ou, ainda, formas de relevo ruiniformes produzidas sobre arenitos e conglomerados muito litificados. Essa grande geodiversidade também implica uma diversidade florística e fisionômica maior, típica do domínio chaquenhopampeano, com gramíneas, leguminosas, arbustos, florestas de encosta e de galeria, além da ocorrência notável de cactáceas e bromeliáceas, com relevante ocorrência de endemismos e adaptações fisiológicas e morfológicas das plantas. Para Rambo (2018), os domínios chaquenhos são "as últimas ondas do pampa argentino, jogadas na Campanha riograndense" (p.145).

\subsection{O Pampa das Mesetas}

Esta ecoprovíncia de cerros tabulares e areais com campos pobres estende-se como uma grande faixa de orientação norte-sul, com cerca de 300 quilômetros de comprimento e aproximadamente 50 quilômetros de largura, desde a cidade de Tacuarembó, no Uruguai, até Unistalda, no Rio Grande do Sul. O substrato rochoso dessa região é formado pelas diferentes camadas de rochas sedimentares avermelhadas do Permiano e do Mesozóico da Bacia do Paraná (Rosário do Sul, 
Pirambóia, Sanga do Cabral, Santa Maria, Guará e Botucatu), estando por vezes recobertas por delgadas camadas de basaltos.

As rochas sedimentares apresentam-se, de um modo geral, em camadas tabulares e horizontais, definindo a formação de cerros dominantemente em forma de mesa, com desníveis de até 200 metros e topos planos, sendo que as áreas da serra do Caverá, em Rosário do Sul, do Cerro Palomas, em Santana do Livramento, e dos Tres Cerros de Cuñapirú, a NE da cidade de Tacuarembó, são emblemáticas desse caráter de "meseta". Espacialmente tais elevações podem se apresentar com formatos desde circular até retilíneo, muito alongado ou recortado por fraturas, dependendo do controle tectônico a que estiveram submetidas no passado.

Com variáveis condições de porosidade e permeabilidade, as paisagens desta ecoprovíncia sustentam desde formações herbáceas na maior parte da área, até formações arbustivas e arbóreas nas faces sul e sudoeste desses cerros tabulares e nos vales encaixados em alinhamentos de fraturas.

Considerando que algumas das rochas sedimentares que formam esta paisagem são pouco litificadas e muito friáveis, tornando-se suscetíveis ao intemperismo físico e químico, a presença de solos arenosos, quartzosos e muito rasos, pobres em nutrientes, acaba aparecendo com muita expressividade nesta área, formando as manchas de areia livre, conhecidas como regionalmente como "areais". Supõe-se que, durante o último máximo glacial, há cerca de 18 mil anos, tais areais tenham sido muito mais extensos (SUERTEGARAY e PIRES DA SILVA, 2009), constituindo hoje, juntamente com a presença marcante de cactáceas, um registro importante dos climas mais frios e secos do passado. Portanto, a conservação destes areais e não a sua "recuperação" (entendida esta como a possibilidade de (re)incorporação destas áreas ao processo produtivo agropecuário), precisa ser uma temática sobre a qual os pesquisadores devem se debruçar.

Além dos areais, a ecoprovíncia se destaca pela atuação de processos erosivos importantes, como ravinas e voçorocas, em função tanto do uso inadequado da terra quanto dos contrastes naturais de permeabilidade entre as diferentes camadas do solo e do subsolo. 


\subsection{O Pampa do Espinilho}

A paisagem formada por planícies fluviais da bacia do rio Uruguai com parque de espinilhos (Vachellia caven) coincide com as áreas cuja vegetação original se constitui, além do estrato herbáceo campestre, de um estrato de arvoretas esparsas (espinilho, algarrobo, inhanduvá, entre outras), bastante representativo no Uruguai, mas preservado no Rio Grande do Sul apenas no Parque Estadual do Espinilho, em Barra do Quaraí, e no Cerro do Jarau, em Quaraí.

Esta ecoprovíncia coincide com a área mapeada como "campo com espinilho" por Hasenack et al. (2010), possuindo duas manchas principais, uma desde São Borja até a cidade de Salto, e outra entre Paysandú e a porção noroeste do Departamento de Colônia, principalmente acompanhando a calha do rio Negro. No Pampa argentino, esta paisagem corresponde à unidade do Espinal (BURKART et. al., 1999).

De acordo com Sell et al. (2015) a principal característica geológica que permite a individualização dessas áreas é o substrato sedimentar, formado por depósitos continentais, aluviais e coluviais acumulados desde o Paleógeno até o Quaternário (ou seja, nos últimos 35 milhões de anos) sobre as rochas vulcânicas da Formação Serra Geral, acompanhando as variações do nível do mar e seus reflexos sobre a mesopotâmia argentina e o estuário do Prata, incluindo grandes transgressões marinhas. As unidades estratigráficas às quais se vinculam tais depósitos recebem, no Uruguai, designações como "Formación Salto" e "Formación Fray Bentos" (DINAMIGE, 1985), enquanto no Rio Grande do Sul há referências a designações como Formação Touro Passo e aloformação Guterres (OLIVEIRA e KERBER, 2009). Grande parte dessa ecoprovíncia é caracterizada por solos orgânicos de alta fertilidade química (os chernossolos e brunosoles), alguns ricos em carbonatos e sais, desenvolvidos exatamente sobre os depósitos quaternários aluviais do rio Uruguai e dos trechos finais de seus afluentes Butuí, Ibicuí, Quaraí, Arapey e Negro.

\subsection{O Pampa Ondulado}

A ecoprovíncia de maior extensão dentro da área de estudo é aquela das planícies e colinas onduladas recobertas por grandes extensões de campos. Esta 
grande unidade de paisagem compreende a as áreas da Depressão Central (ou Periférica) do Rio Grande do Sul, a maior parte da fronteira oeste gaúcha e a Cuesta do Haedo, bem como os terrenos cristalinos do cráton Rio de La Plata, no Uruguai.

Mesmo com diversidades geológico-geomorfológicas, esta paisagem é a que guarda as características culturais e fisionômicas mais prontamente associadas ao Pampa, já que, neste caso, as características de geomorfologia e fisionomia dependem muito menos do substrato geológico (geodiversidade) e muito mais de fatores ligados ao clima, à evolução das vertentes, à sucessão ecológica em si e à forma de ocupação humana. Ainda assim, cabe destacar aqui a presença de feições paisagísticas diferenciadas dentro desta grande ecoprovíncia: (a) a feição de campos sobre solos rasos do oeste gaúcho e uruguaio, vinculados às rochas de composição andesítica da Formação Serra Geral, por vezes muito fragmentadas, dão origem aos "campos de pedra" que forneceram, ao longo da história, os blocos para a construção das taipas e currais de pedra típicos da região; (b) presença de feições de pequenas elevações, muito localizadas ou com pouco destaque na paisagem, como nas chamadas "Sierras de Mahoma", no norte do Departamento de San José, ou nos campos de matacões de Marincho, aparecem como resultante da presença de corpos graníticos intrusivos; c) já no Departamento de Flores, em cujo território estão as "Grutas del Palacio", há o registro de ferrificação sobre rochas sedimentares, definindo este importante monumento natural que ensejou a certificação daquele departamento como Geoparque da UNESCO; e (d) presença de algumas elevações isoladas na Depressão Central gaúcha, morfologicamente semelhantes às do "Pampa das Mesetas", mas fora de sua faixa mais característica, como no caso dos cerros do Loreto e Seio de Moça, entre os municípios de São Vicente do Sul e Cacequi.

\section{GEOPATRIMÔNIO DO PAMPA E TRANSFORMAÇÕES DA PAISAGEM}

A grande geodiversidade do Pampa Uruguaio Sul-Rio-Grandense, forjada por uma riqueza de processos orogenéticos e distintos e sucessivos paleoambientes na escala geológica de tempo, é responsável por sustentar uma riquíssima 
biodiversidade atual e uma cultura humana que moldou e foi moldada pela paisagem no processo histórico de transformação da natureza. A paisagem, neste contexto, é, ao mesmo tempo, o produto e o agente de transformação da cultura ou, como afirma Campelo (2013), "elemento dialógico na identidade cultural da comunidade que a interpreta e pratica, integrando a experiência enquanto conhecimento imaginativo e fecundo" (p.25).

Nesse complexo sistema geo-bio-cultural do Pampa, a ocorrência de feições geológico-geomorfológicas com demandas de conservação atribuídas pelos seus valores científico, educativo ou turístico, representa mais do que a presença de sítios geopatrimoniais (geossítios); elas representam verdadeiros marcos da vida humana no Pampa, guardando, seja na forma material (estruturas e processos demarcados na paisagem), seja na forma imaterial (nas lendas, nas poesias, nas músicas e nas danças) o registro da evolução da Terra e da cultura humana que se desenvolveu sobre ela.

Toda esta riqueza (abiótica, biótica e cultural) tem sido profundamente ameaçada nas últimas décadas pelo avanço acelerado de um processo de territorialização do grande capital, associado à produção de commodities (FIGUEIRÓ, 2017), responsável por uma aceleração dos processos erosivos e perda sistemática da vegetação campestre e dos seus banhados característicos, de maneira que restam hoje, no território brasileiro, apenas 39\% da cobertura vegetal original (PICOLLI E SCHNADELBACH, 2007). Entre os anos de 1970 e 2005, segundo as autoras (op. cit.), estima-se que 4,7 milhões de hectares de pastagens nativas tenham sido convertidos em outros usos agrícolas, como lavouras e plantações de árvores exóticas. No Uruguai, segundo Gudynas e Evia (2000), mais de $80 \%$ do território se encontra sob algum tipo de uso agropecuário, com diferentes níveis de intensidade, comprometendo o aproveitamento educativo e científico de patrimônios naturais de grande relevância para o Pampa (figura 5). 
Figura 5 - O avanço da produção de commodities em larga escala no Pampa Uruguaio-sul-rio-grandense tem promovido uma modificação estrutural profunda na paisagem de grande parte deste território, colocando em risco a conservação do seu patrimônio natural. Nas fotos, destaque para o cultivo de espécies exóticas transformando a paisagem fluvial do Arroio Grande (Departamento de SorianoUruguay) à esquerda e do Cerro Solito (Departamento de Rivera-Uruguay) à direita

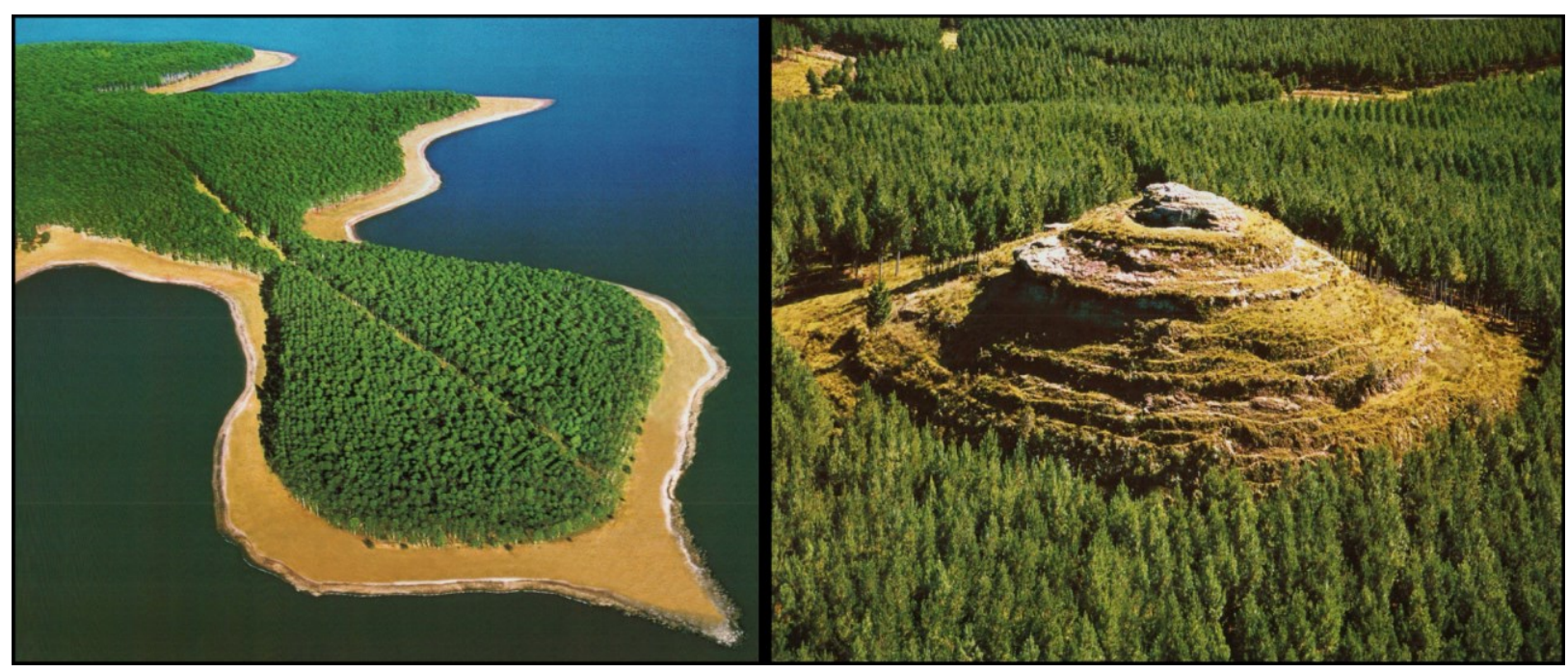

Fonte: Testoni Studios (2010).

Diante dessa realidade, é urgente a necessidade de que seja desencadeado um processo de geoconservação que não apenas possa fazer frente a esse avançado processo de destruição da paisagem do Pampa, mas que, também, seja capaz de potencializar uma redefinição das estratégias de desenvolvimento territorial local, buscando alicerçar a melhoria das condições econômicas e sociais daquela população no aproveitamento sustentável do seu geopatrimônio e do patrimônio biocultural dessa ecoregião marcada pela permanência de um saber ambiental singular, que se encontra hoje bastante ameaçado pelas promessas de um progresso iluminista capitaneado pelos modelos globais de produção, que colocam o mercado acima da natureza e das pessoas e sua cultura.

Buscando contribuir com este processo de inventariação dos geossítios mais relevantes do Pampa Brasil-Uruguai, buscou-se uma primeira aproximação por meio do estabelecimento de uma relação dos potenciais geossítios com geopatrimônio mais expressivo deste território. Para isso, utilizou-se uma metodologia baseada em Coratza e Giusti (2005), Brilha (2016) e Silva et al (2018), envolvendo o destaque dado 
pela bibliografia, a experiência de campo dos autores associada à informação de um painel de especialistas consultados e, também, a valorização atribuída pela sociedade em geral ao geopatrimônio nas redes sociais, a partir do filtro de um conjunto de hashtags consultados.

A partir deste levantamento, buscou-se definir a localização geográfica dos geossítios identificados a partir de um banco de imagens georeferenciadas dos autores, complementando com a busca no software Google Earth para aqueles geossítios que ainda não se dispunha da localização precisa. Com base nesta localização, estabeleceu-se o mapeamento pontual dos geossítios identificados, sobrepondo às ecoprovíncias previamente definidas e agrupando os geossítios em doze categorias temáticas distintas, conforme os processos de formação ou a estrutura geomorfológica que expressa na paisagem (figura 6).

Figura 6 - Mapa de localização dos 51 geossítios, classificados em 12 categorias temáticas, identificados nesta primeira fase de inventariação do Pampa Brasil-Uruguai

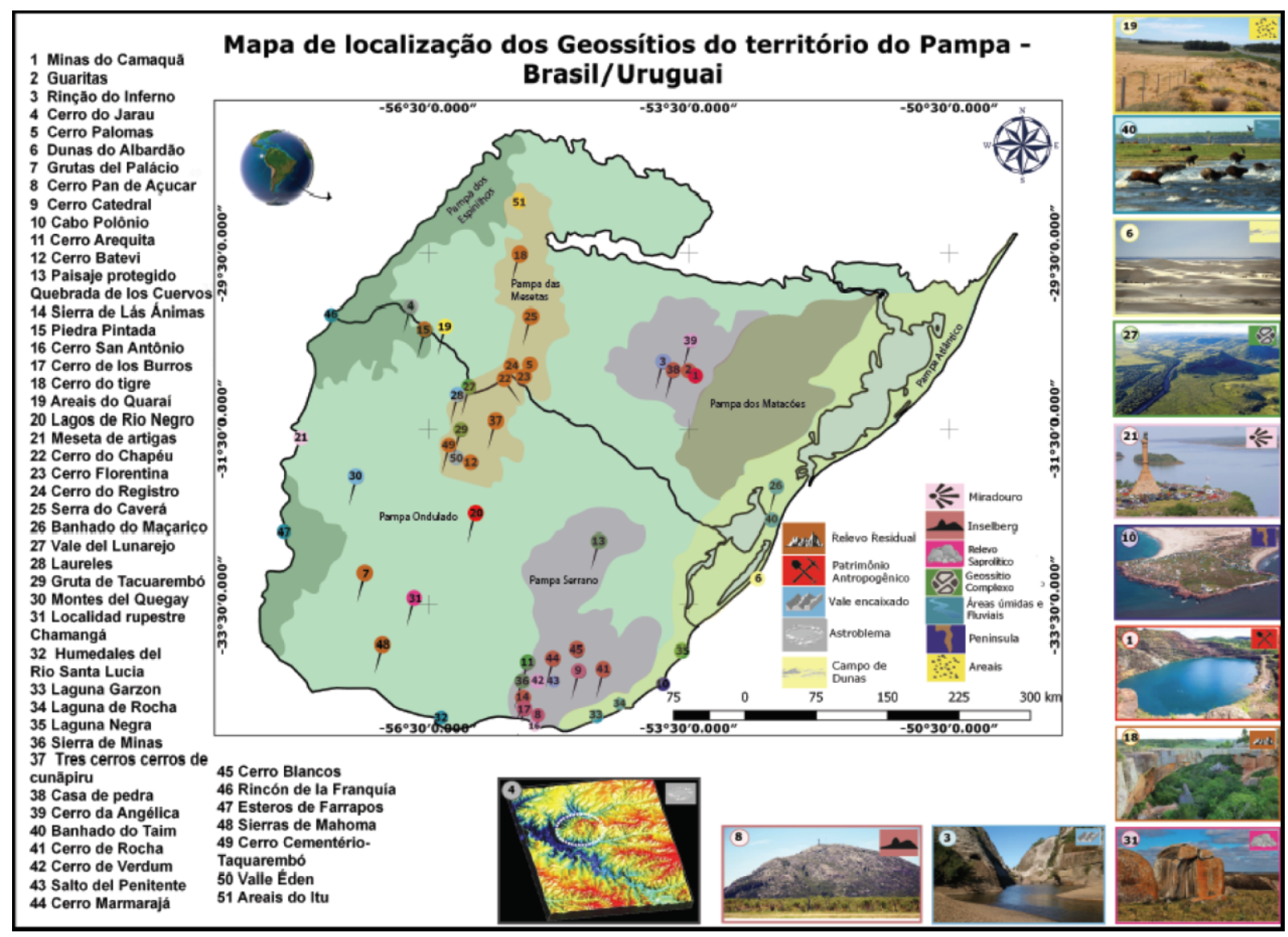

Fonte: Elaboração dos autores 
Nesta primeira fase, foram identificados 51 geossítios mais expressivos no Pampa Brasil-Uruguai, envolvendo as seguintes categorias temáticas:

a) Relevo residual: incluíram-se aqui todas as feições ruiniformes de diferentes litologias, que demarcam a ação do desgaste intempérico sobre estruturas geomorfológicas soerguidas ou geomonumentos que testemunham a ação erosiva sobre superfícies pretéritas. No conjunto do pampa Brasil-Uruguai esta categoria é mais facilmente encontrada nas ecoprovíncias do Pampa das Mesetas e do Pampa Serrano, que são justamente as estruturas de relevo mais destacadas de todo o território. Ao total, foram identificados 18 geossítios dentro desta categoria, com especial destaque para o Geossítio Guaritas, em Caçapava do Sul, cujo valor estético de uma geomorfologia ruiniforme esculpida sobre arenitos e conglomerados, the valeu a inclusão na lista de inventário da Comissão Brasileira de Sítios Geológicos e Paleobiológicos (PAIM et al, 2013).

b) Patrimônio antropogênico: esta categoria se refere a estruturas geomorfológicas "esculpidas" pela ação humana de forma permanente sobre a paisagem; na área de pesquisa, foi dado destaque a dois geossítios importantes dentro desta categoria, sendo eles a localidade de Minas do Camaquã, em Caçapava do Sul - Brasil e os Lagos de Rio negro, no Uruguai. No primeiro caso, a paisagem testemunha as heranças da maior exploração de cobre a céu aberto já realizada no Brasil, o que garantiu a este geossítio a sua inclusão na lista de inventário da Comissão Brasileira de Sítios Geológicos e Paleobiológicos (PAIM, 2002). No segundo caso, o geossítio está representado pela construção de três grandes represas no rio Negro, afluente do rio Uruguai, sendo elas as represas de Rincón del Bonete, Baygorria e Palmar; juntas, elas não apenas garantem a regularização da vazão do rio e sua navegabilidade nos últimos $80 \mathrm{Km}$ antes da foz, como fornecem a maior parte da energia elétrica utilizada no Uruguai.

c) Vale encaixado: incluem-se nesta categoria cinco geossítios identificados, onde a energia fluvial promoveu um trabalho erosivo sobre rochas mais friáveis e/ou aproveitando-se de linhas de falhamento capazes de definir um "encaixe" dos cursos dágua em vales mais profundos, na maior parte das vezes acompanhados de 
ressaltos em pontos de maior dureza (knickpoints), capazes de produzir belíssimos cenários de quedas d'água, extremamente apreciados pelos visitantes. Destacam-se aqui os geossítios de Laureles, Rincão do inferno, Valle éden, Montes de Quegay e Salto del Penitente. O primeiro deles, como parte de uma Reserva da Biosfera do Uruguai (Reserva da Biosfera Quebradas del Norte), constitui um mosaico de ecossistemas em um relevo montanhoso com variações altimétricas que se aproximam dos 400 metros, o que representa uma excepcionalidade para a ecoregião do Pampa Brasil-Uruguai. Já o último (salto del Penitente), representa uma área protegida de 45 hectares no departamento de Lavalleja, onde se destaca uma cachoeira com mais de 60 metros de altura, extremamente demandada pelos turistas.

d) Astroblema: esta categoria temática, referente a estruturas geomorfológicas produzidas pela queda do espaço de um meteorito ou cometa, aparece no território pesquisado com um único e importante representante: o Cerro do Jarau. Localizado no município de Quaraí, esta forma de relevo com mais de 200 metros de altura demarca as bordas de uma antiga cratera de 3,5 quilômetros de diâmetro, produzida pela queda de um corpo celeste a aproximadamente 117 milhões de anos atrás (SÁNCHEZ et al, 2014). Este geossítio se eternizou na cultura gaúcha por meio da lenda da Salamanca do Jarau, criada pelo escritor gaúcho João Simões Lopes Neto, e que conta a história de uma princesa moura (Teiniaguá), fugida do último reduto árabe na Espanha, que veio para o Brasil transfigurada em uma velha e se abrigou em uma furna do Cerro do Jarau, até ser descoberta por um sacerdote jesuíta que acaba se apaixonando por ela.

e) Campo de Dunas: optou-se por relacionar nesta categoria temática um único e mais expressivo representante dos sistemas deposicionais do tipo laguna-barreira que formam o litoral do Pampa Atlântico. O geossítio das Dunas do Albardão, localizado no município de Santa Vitória do Palmar, apresenta cerca de 100 km de extensão, constituindo uma extensa faixa arenosa entre o Oceano Atlântico e a Lagoa Mangueira. A paisagem é caracterizada pela presença de extenso campo de dunas (móveis, frontais e incipientes) de grande beleza cênica, altura expressiva e 
importância ambiental, fazendo fronteira ao norte com o Banhado do Taim. Para além do reconhecimento dos campos de dunas como patrimônio geológico, a área é também caracterizada pela presença de sítios de interesse arqueológico e paleontológico, o que aumenta a sua importância científica, tendo por isso sido inventariada dentro da lista dos sítios geológicos e paleontológicos do Brasil - SIGEP (LOPES et al, 2009).

f) Miradouros: incluíram-se aqui quatro geossítios que representam plataformas privilegiadas de observação da paisagem circundante. Diferentemente das demais categorias temáticas, onde o geossítio representa uma porção do espaço que contêm estruturas e/ou processos de valor geopatrimonial significativo e que, graças a isso, merece ser protegido de alterações profundas, o miradouro representa uma porção do espaço que não necessariamente contêm o geopatrimônio, mas de onde se pode ter uma visão privilegiada das paisagens com valor patrimonial. Neste caso, o miradouro representa um geossítio que merece ser preservado pela sua posição e não necessariamente pelo seu conteúdo, o qual, na maior parte das vezes, representa uma área muito mais ampla que circunda o miradouro. Dentro desta temática o destaque fica para os geossítios do Cerro San Antônio (localizado no município de Piriápolis, departamento de Maldonado, Uruguai) e Meseta de Artigas (departamento de Paysandú, Uruguai). O Cerro San Antônio representa um dos geomonumentos desenvolvidos sobre o complexo vulcânico Sierra de las Animas, que compreende um filão magmático de 130 metros de altura que preenche um rift de direção norte-sul pós ciclo brasiliano, de onde se pode observar toda a baía que cerca a cidade de Piriápolis, com o cerro Pan de Azúcar ao fundo. No topo do cerro encontra-se o templo de San Antonio, cuja imagem de terracota foi trazida de Milão, Itália. Já a Meseta de Artigas representa um promontório de aproximadamente 50 metros de altura sobre o rio Uruguai onde, em 1899, se erigiu um monumento a José Gervasio Artigas (declarado monumento histórico nacional em 2003), militar uruguaio envolvido na guerra da independência daquele país. Para além do aspecto panorâmico de observação do rio Uruguai, o geossítio apresenta um grande valor cultural, tendo em vista o evento anual que ali se comemora no mês de setembro em 
honra do aniversário de morte de Artigas, denominado "Encuentro con el Patriarca", e para o qual afluem milhares de visitantes provenientes de distintas regiões do país.

g) Inselbergs: independente da constituição geológica, agruparam-se nesta categoria temática aqueles geomonumentos que correspondem a relevos residuais de elevada dimensão que se destacam nas planícies circundantes, como testemunhos de resistência aos processos de pediplanação em diferentes condições climáticas. 0 destaque nesta categoria fica para o geossítio do Cerro Catedral, localizado no departamento de Maldonado e considerado o ponto mais alto do Uruguai, com pouco mais de 513 metros de altitude. Este geossítio em particular encontra-se com a paisagem bastante ameaçada diante da instalação do parque eólico da "Sierra de Carapé", em 2015, com uma potência instalada de 90 MW (figura 7).

h) Relevo Saprolítico: sendo um relevo conhecido no campo da geomorfologia como "Tor", esta denominação envolve a presença de relevos residuais formados pelo afloramento de materiais de maior dureza e resistência ao intemperismo. A direção do sistema de faturamento, associada à dureza da rocha e à intensidade do processo de intemperização define a arquitetura desta categoria geopatrimonial, desde complexas estruturas de empilhamento de rochas até um conjunto de blocos dispersos. Neste primeiro inventário do Pampa Brasil-Uruguai, destacamos um único representante para a categoria de relevo saprolítico, representado pelo geossítio da "Localidad Rupestre de Chamangá", localizada a leste do município de Trinidad, no departamento de Flores. Esta área de mais de 12.000 ha constitui uma paisagem protegida dentro do Sistema Nacional de Áreas Protegidas do Uruguai, por representar um campo de blocos graníticos que guarda a maior concentração de pinturas rupestres do país, com 43 pinturas inventariadas e que têm a particularidade de não terem sido feitas em cavernas, mas em blocos ao ar livre. Os esforços do governo uruguaio é para que este geossítio seja incluído na lista dos sítios do patrimônio mundial da UNESCO. 
Figura 7 - A paisagem do Cerro Catedral, considerado como o ponto de maior elevação do Uruguai (em primeiro plano, o marco geodésico do cerro), encontra-se transformada pela instalação do parque eólico da "Sierra de Carapé". Em todo o mundo, a compatibilização entre a proteção paisagística e a produção de energia eólica tem representado um grande desafio ao processo de geoconservação

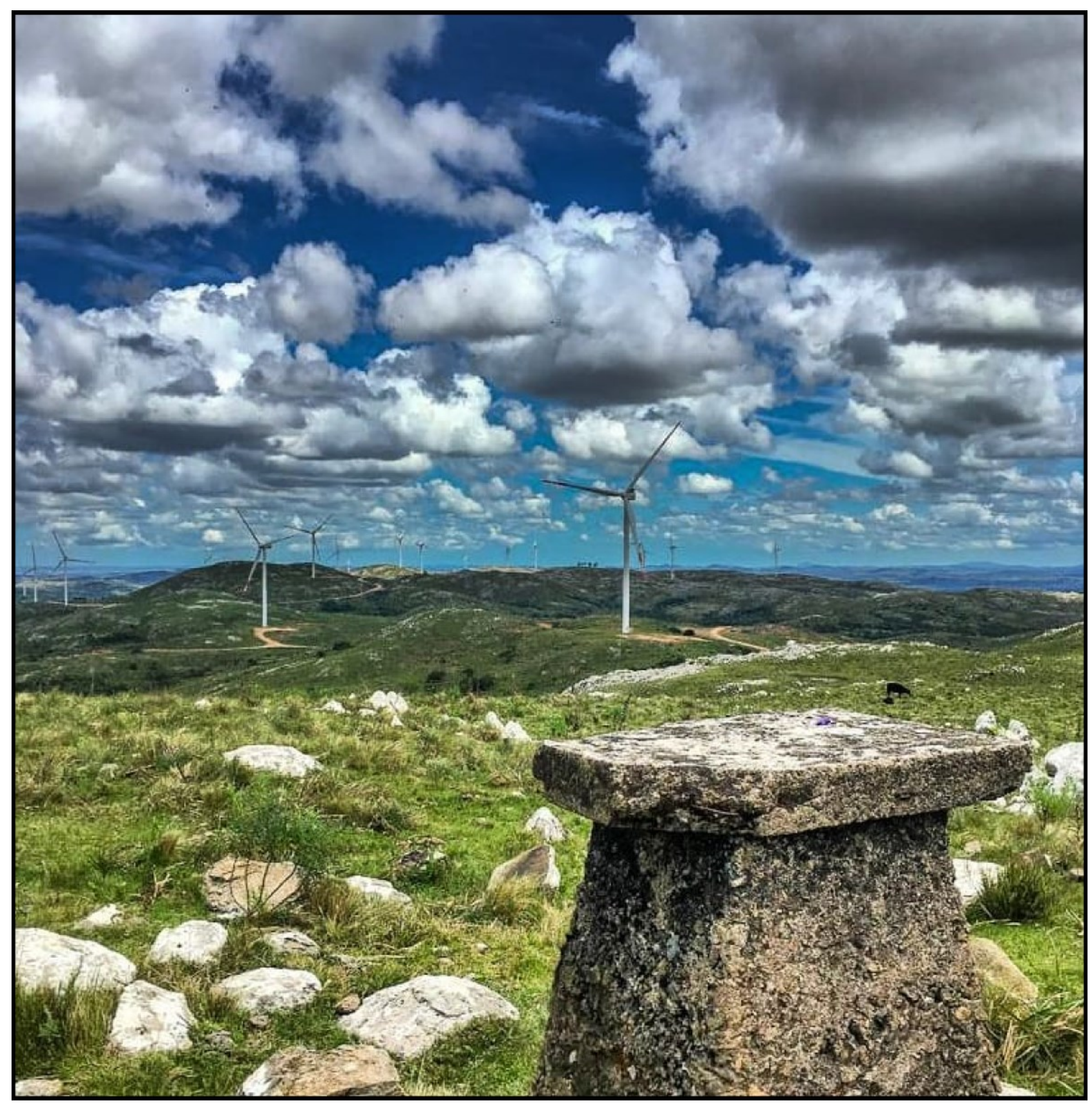

Fonte: http://picpanzee.com/place/519591105.

i) Geossítio Complexo: esta categoria temática envolve geossítios com elevado grau de diversidade paisagística, de maneira que em um mesmo local se podem interpretar diferentes tipos de atrativos e valores patrimoniais associados tanto à geodiversidade quanto à biodiversidade. Dentre os seis geossítios inventariados nesta 
categoria estão, por exemplo, o Vale del Lunarejo, representado por uma paisagem de vales com grande beleza cênica entalhados no reverso da Cuesta de Haedo, e que cumprem uma função de corredor biológico para o ingresso de espécies subtropicais de flora e fauna do sul do Brasil até o território uruguaio. Nesta paisagem registra-se a ocorrência de cavernas, paredões verticais e quedas d'água e se desenvolve uma exuberante vegetação do tipo floresta subtropical, com rica biodiversidade.

j) Áreas úmidas e fluviais: incluem-se nesta categoria temática sete geossítios cujo principal destaque patrimonial está ligado às zonas úmidas, capazes de sustentar uma grande riqueza de biodiversidade. A importância destas paisagens não se reduz, por certo, à sustentação dos habitats de fauna, como também ao controle e regulação do fluxo hidrológico regional. Um dos principais destaques nesta categoria se refere ao geossítio do banhado do Taim, entre os municípios de Rio Grande e Santa Vitória do Palmar. A importância deste geossítio reside na grande variedade de ecossistemas ali presentes, representados por praias lagunares e marinhas, lagoas, pântanos, restingas, campos, cordões e campos de dunas, sendo por isso uma das mais importantes e reconhecidas unidades de conservação dentro do Pampa gaúcho. Não menos importante nesta categoria, é o geossítio de Esteros de Farrapos, no Uruguai, constituindo um sistema de áreas úmidas com rios, ilhas e banhados que são essenciais no controle do nível da água do rio Uruguai no oeste do país. Tal importância the rendeu a criação de uma das mais importantes unidades de conservação do país, o Parque Nacional "Esteros de Farrapos e Islas del Río Uruguay".

k) Península: derivada de sua importância como estrutura geomorfológica à qual se associa uma beleza cênica decorrente de uma bacia visual de grande amplitude, esta categoria abrange aquelas áreas de terra que são cercadas de água por quase todos os lados, exceto por um istmo que a une à massa continental. Neste inventário, tal categoria aparece com um único representante, mundialmente reconhecido pelo atrativo turístico que representa no Uruguai, que é o geossítio do cabo Polônio, uma área protegida localizada no departamento de Rocha. Dentro do Parque Nacional Cabo Polonio encontra-se uma importante reserva de lobos marinhos e um farol instalado em 1881. A beleza cênica da área associada à 
biodiversidade que ali existe e a riqueza cultural de uma comunidade tradicional de pescadores e artesãos, faz com que este geossítio represente um dos principais destinos de turismo de natureza dentro do Uruguai.

I) Areais: esta categoria temática envolve aqueles geossítios que testemunham a formação do solo associado à dinâmica hídrica e à ação dos ventos no oeste gaúcho durante o holoceno. Durante muitos anos tratadas como "áreas degradadas", estes areais, que ao todo somam mais de 20.000 hectares de sedimentos arenosos inconsolidados, representam um belíssimo testemunho não apenas do processo de transição de um paleoambiente mais seco para um período mais úmido, mas, sobretudo, dos processos adaptativos de plantas, animais e do próprio homem a esta consição natural de fragilidade da paisagem. Para esta primeira versão do inventário, optou-se em destacar dois grandes geossítios que envolvem diferentes manchas de arenização, sendo eles os areais do Itú e os areais do Quaraí.

\section{CONCLUSÕES}

Este artigo representa uma primeira aproximação de um inventário geopatrimonial em larga escala da ecoregião do Pampa Brasil-Uruguai. Nesta primeira listagem de 51 geossítios mapeados, observa-se que as ecoprovíncias do Pampa das Mesetas e do Pampa Serrano são as que guardam as maiores ocorrências de estruturas com valores geopatrimoniais, ainda que importantes geossítios destacados ocorram em outras unidades de paisagem, dependendo da categoria temática a que se refere. Além disso, a ação intensa dos processos morfogenéticos ao longo do tempo sobre esta paisagem, nos permitiu identificar que a categoria de relevos residuais acabou por ser a prevalecente em toda a área estudada.

A lista de geossítios do inventário continua aberta para novas inclusões e/ou reavaliações de geossítios incluídos, de maneira que se possa chegar, ao final deste projeto, em um inventário que, de fato, represente o valor geopatrimonial mais expressivo desta porção do pampa, compartilhada entre os dois países. No contexto de processos de transformação da paisagem tão acelerados, que têm levado a perdas 
significativas de valores patrimoniais a elas associados, é urgente que se aprofunde a reflexão e a proposição de estratégias comuns de proteção aos territórios brasileiro e uruguaio, que compartilham uma paisagem única, ainda que diversa, e que encontrase submetida às mesmas forças de transformação/destruição, ainda que em ritmos e intensidades diferentes. Esta necessidade aponta no sentido da fragilidade deste sistema jurídico-político de uma soberania nacional que afasta os países e fragmenta os esforços de conservação.

Ainda no que se refere ao inventário, da mesma forma que a listagem, a definição das categorias temáticas poderá sofrer uma nova revisão para futuras versões deste estudo, de maneira a contemplar a riqueza da geodiversidade existente no território.

Nas etapas seguintes, para além de uma revisão constante da listagem de geossítios, o processo de inventariação deverá incluir uma delimitação espacial mais precisa para cada geossítio, além de uma caracterização mais detalhada de cada um, apontando os principais valores geopatrimoniais associados e as ameaças existentes à sua conservação.

Por fim, cumpre destacar que esta inventariação se desenvolve no sentido de incorporar elementos de atratividade ao território, por meio de uma ampliação das atividades de geoturismo, o que implica pensar conexões territoriais que interliguem estes geossítios em "corredores de geodiversidade" capazes de ampliar a experiência geoturística dos visitantes. Para tanto, a discussão de estradas paisagísticas (SELL, 2017) que permitam "fluir e interpretar", garantindo a conservação patrimonial e a geração de desenvolvimento territorial endógeno associado a esta conservação, é um dos elementos sobre os quais se está refletindo neste momento e que deverá gerar novas publicações no futuro.

\section{AGRADECIMENTOS}

Os autores agradecem ao CNPq pelo financiamento desta pesquisa. 


\section{REFERÊNCIAS}

ACHKAR, M.; CANTÓN, VÍCTOR; DÍAZ, ISMAEL; DOMÍNGUEZ, ANA; FACCIO, CAROLINA; FERNÁNDEZ, GABRIELA et al. Áreas protegidas: un desafío en el ordenamiento ambiental del territorio. Montevideo: Universidad de la República; 2010.

ALEXANDER, D. Bioregionalism; The need for a firmer theoretical foundation. The Trumpeter Journal of Ecosophy, 13(3); 1996. Disponível em: http://trumpeter.athabascau.ca/index.php/trumpet/article/view/260/385. Acesso em: 15 de maio de 2015.

BAILEY, R. G. Ecoregion - based design for sustainability. New York: Springer; 2002. BEHLING, H.; ESKE-PIERUSCHKA, V.; SCHÜLER, L.; PILLAR, V.P. Dinâmica dos campos no sul do Brasil durante o Quaternário tardio. In: PILLAR, V. P.; MULLER, S.C.; CASTILHOS, Z.M.S.; JACQUES, A.V.A. (Eds.) Campos Sulinos: conservação e uso sustentável da biodiversidade. Brasília: MMA; 2009.p. 13-25.

BERG, P.; DASMANN, R. Reinhabiting California. In: PEPPER, D.; WEBSTER, F.; REVILL, G. (Eds.). Environmentalism. Critical concepts. London: Routledge; 2003. p.231-236.

BERNÁLDEZ, F.G. Invitación a la Ecologia Humana. La adaptación afectiva al entorno. Madrid: Editorial Tecnos; 1985.

BOLDRINI, I.L., FERREIRA, P.M.A., ANDRADE, B.O., SCHNEIDER, A.A., SETÚBAL, R.B., TREVISAN, R. \& FREITAS, E.M. Bioma Pampa: Diversidade florística e fisionômica. Porto Alegre: Pallotti; 2010.

BORBA, A. W.; SOUZA, L.F.; MIZUSAKI, A.M.P.; ALMEIDA, D.P.M.; STUMPF, P.P.. Inventário e avaliação quantitativa de geossítios: exemplo de aplicação ao patrimônio geológico do município de Caçapava do Sul (RS, Brasil). Pesquisas em Geociências, 40(3): 275-294, 2013.

BOSSI, J.; NAVARRO, R. Geología del Uruguay. 2 vol. Montevidéu: Universidad de la República; 1991.

BRAILOVSKY, A.E. Historia Ecológica de Iberoamérica. De los Mayas al Quijote. Buenos Aires: Capital Intelectual; 2006.

BRILHA, J. Inventory and Quantitative Assessment of Geosites and Geodiversity Sites: a Review. Geoheritage, (8):119-134, 2016.

BURKART, R.; N. O. BARBARO; R. O. SÁNCHEZ y D. A. GÓMEZ, Ecorregiones de la Argentina. Buenos Aires: Administración de Parques Nacionales, 1999.

CAMPELO, A. A paisagem. Introdução a uma gramática do "espaço". Guimarães: UMINHO, 2013.

CHEMALE Jr., F. Evolução geológica do Escudo Sul-rio-grandense. In: HOLZ, M.; DE ROS, L.F. (Eds.) Geologia do Rio Grande do Sul. Porto Alegre: Edições CIGO/UFRGS; 2000. p. 13-52. 
CORATZA, P.; GIUSTI, C. Methodological proposal for the assessment of the scientific quality of geomorphosites. II Quaternario - Italian Journal of Quaternary Sciences, 18(1): 307-313, 2005.

CÓRDOVA, J.P. La disputa por el patrimonio biocultural. Un acercamiento desde Mesoamérica. In: PAREJA, M.C.; ROMERO, L.E.A. (Coords.) Patrimonio Biocultural, Territorio y Sociedades Afroindoamericanas en Movimiento. Buenos Aires: CLACSO, 2013. p.17-30.

CPRM - COMPANHIA DE PESQUISA DE RECURSOS MINERAIS. Mapa da geodiversidade do Rio Grande do Sul. Brasília: SGMTM-CPRM; 2009.

CTI- COMITÊ TÉCNICO INTERAGENCIAL. Fundamentos territoriales y bioregionales de la planificación. Bridgetown, Barbados: Foro de Ministros de Medio Ambiente de América Latina y el Caribe; 2000.

DINAMIGE - DIRECCIÓN NACIONAL DE MINERÍA Y GEOLOGÍA. Carta geológica del Uruguay a escala 1:500.000. Montevideo, DINAMIGE;1985.

FIGUEIRÓ, A.S. Transformações na paisagem do Pampa: a territorialização do capital e a monopolização do território. In: WIZNIEWSKY, C.R.F.; FOLETO, E. (Orgs.) Olhares sobre o Pampa: um território em disputa. Porto Alegre: Evangraf; 2017. p. 140-168.

FIGUEIRÓ, A.S. Memória, Cultura e Resiliência na Compreensão da Paisagem do Pampa: Contribuição para uma Geografia integradora. In: GOMEZ, I.A. (Org.) A Produção do Conhecimento Geográfico 2. Ponta Grossa: Atena Editora; 2018. p. 179-194.

FONSECA, A.A.M. Em torno do conceito de região. Sitientibus, (21):89-100; 1999.

GONZÁLEZ DE MOLINA, M.; TOLEDO, V.M. Metabolismos, Naturaleza e Historia: hacia una teoría socio-ecológica de las transformaciones. Barcelona: Icaria editorial; 2011.

GUDYNAS, E.; EVIA, G. Ecología del paisaje en Uruguay: aportes para la conservación de la Diversidad Biológica. Sevilla: Junta de Andalucía - Consejería de Medio Ambiente; 2000.

GUDYNAS, E. (Org.) Sustentabilidad y Regionalismo en el Cono Sur. Montevideo: Editorial Coscoroba; 2002.

HARTMANN, L. A., PORCHER, C.C. \& REMUS, M.V.D. Evolução das rochas metamórficas do Rio Grande do Sul. In: HOLZ, M.; DE ROS, L.F. (Eds.) Geologia do Rio Grande do Sul. Porto Alegre: Edições CIGO/UFRGS; 2000.p. 79-118.

HASENACK, H.; WEBER, E.; BOLDRINI, l.; TREVISAN, R. Mapa de sistemas ecológicos da ecorregião das Savanas Uruguaias em escala 1:500.000. Porto Alegre: UFRGS/Centro de Ecologia; 2010.

HONG, S.K. Philosophy and Background of Biocultural Landscapes. In: HONG, S.K.; BOGAERT, J.; MIN, Q. (Eds.) Biocultural Landscapes. Diversity, Functions and Values. London: Springer, 2014. P.1-8 
LINDMAN, C. A. M.; FERRI, M.G. A vegetação no Rio Grande do Sul. Belo Horizonte/São Paulo: Itatiaia/EDUSP; 1974.

LIPSCHUTZ, R. Bioregionalism, Civil Society and Global Environmental Governance. In: McGINNIS, M.V. (Ed.). Bioregionalism. New York: Routledge; 2005. p. 61-80.

LOPES, R.; UGRI, A.; BUCHMANN, F. Dunas do Albardão, RS. Bela paisagem eólica no extremo sul da costa brasileira. In: WINGE, M. et al. Sítios Geológicos e Paleontológicos do Brasil. Vol.II. Brasília: CPRM, 2009. p.131-140.

MENEGAT, R. O DNA da paisagem. In: PAIVA, Z. Expedição Natureza Gaúcha. São Paulo: Metalivros; 2008.

MMA- MINISTÉRIO DO MEIO AMBIENTE. Avaliação e ações prioritárias para a conservação da biodiversidade da Mata Atlântica e Campos Sulinos. Brasília: MMA/SBF; 2000.

NORGAARD, R. Development Betrayed: The end of progress and coevolutionry revisioning of the future. London : Routledge, 1994.

OLIVEIRA, E.V.; KERBER, L. Paleontologia e aspectos geológicos das sucessões do fi nal do Neógeno no sudoeste do Rio Grande do Sul, Brasil. Gaea - Journal of Geoscience, 5 (1): 21-34, jan/jun 2009.

OLSON, D.M.; INERSTEIN, E.; WIKRAMANAYAKE, E.D.; BURGESS, N.D.; POWELL, G.V.N.; UNDERWOOD, E.C. et al. Terrestrial Ecoregions of the World: A new map of life on earth. BioScience, 51 (11): 933-938; 2001.

PAIM, P.S.G. Minas do Camaquã, RS. Marco da história da mineração de cobre no Brasil. In: SCHOBBENHAUS, C. et al (Eds.). Sítios Geológicos e Paleontológicos do Brasil. Vol. I. Brasília: DNPM, 2002. p.501-510.

PAIM, P.S.G.; FALLGATTER, C.; SILVEIRA, A.S. Guaritas do Camaquã, RS. Exuberante cenário com formações geológicas de grande interesse didático e turístico. In: WINGE, M. et al (Eds.). Sítios Geológicos e Paleontológicos do Brasil. Vol. Ill. Brasília: DNPM, 2013. p.237-250.

PHILIPP, R.P., NARDI, L.V.S. \& BITENCOURT, M.F.A.S. O Batólito Pelotas no Rio Grande do Sul. In: Holz, M.; De Ros, L.F. (Eds.) Geologia do Rio Grande do Sul. Porto Alegre: Edições CIGO/UFRGS, 2000. pp. 133-160.

PICOLLI, L.R., SCHNADELBACH, C. V. (coords.) O Pampa em Disputa: A biodiversidade ameaçada pela expansão das monoculturas de árvores. Porto Alegre: Amigos da Terra Brasil, 2007.

PILLAR, V.P. (Ed.). Campos Sulinos: Conservação e uso sustentável da biodiversidade. Brasília: MMA; 2009.

PRECIOZZI, F., MASQUELIN, H. \& SÁNCHEZ, L. Geología de la porción sur del Cinturón Cuchilla Dionisio. In: Primer Simposio Internacional del Neoproterozoico/Cámbrico de la Cuenca del Plata. Anais... La Paloma (Uruguai):sec, 1993.

RAMBO, B. A Fisionomia Do Rio Grande do Sul. São Leopoldo: UNISINOS, 2018. 
RIETH, F. Inventário Nacional de Referências Culturais - lidas campeiras na região de Bagé/RS. Vol.1. Pelotas: Complexo Criativo Flor de Tuna, 2013.

SÁNCHEZ, J.P; SIMÕES, L.S.A.; MARTINS, L.E.B. Estratigrafia e estrutura do Cerro do Jarau: nova proposta. Brazilian Journal of Geology, 44(2): 265-276, 2014.

SELL, J.C., FIGUEIRÓ, A.S. e BORBA, A.W. Ecoprovíncias do pampa uruguaiosul- riograndense. I Simposio de Geografia do Cone Sul: desafios para la integración de la Geografía del Cono Sur. Anais... Montevideo (Uruguai): UDELAR, 2015

SCIFONI, S. A Construção do Patrimônio Natural. São Paulo: FFLCH; 2008.

SELL, J.C. Estradas Paisagísticas: Estratégia de Promoção e Conservação do Patrimônio Paisagístico do Pampa Brasil-Uruguai [thesis]. Santa Maria: Programa de Pós-Graduação em Geografia/UFSM; 2017.

SEMA - SECRETARIA ESTADUAL DO MEIO AMBIENTE - GOVERNO DO RIO GRANDE DO SUL. Zoneamento Ambiental da Silvicultura: Estrutura, Metodologia e Resultados. Vol. I. Porto Alegre: SEMA; 2010.

SILVA, J.F.A.; NUNES, H.K.B.; AQUINO, C.M.S. Estratégias de valorização e divulgação de geomorfossítios da microrregião de Picos (Piauí), com vistas a sua utilização pelo geoturismo. Terr@Plural, 12 (3): 332-345, set./dez. 2018.

STERN, D.I. The capital theory approach to sustainability; a critical appraisal. Journal of Economic Issues, (31) 1: 145-173; 1997.

SUERTEGARAY, D.M.A., PIRES DA SILVA, L.A. Tche Pampa: Histórias da natureza Gaúcha. In: PILLAR, V.P; MULLER, S.C.; CASTILHOS, Z.M.S.; JACQUES, A.V.A. (Eds). Campos Sulinos: Conservação e uso sustentável da biodiversidade. Brasília: MMA; 2009. p.42-62.

TESTONI STUDIOS (Ed.). Uruguay. Uma mirada desde el cielo. Montevideo: Testoni Studios Ediciones, 2010.

THOMAS, D.S.G.; ALLISON, R.J. Landscape Sensitivity. London: Wiley; 1993.

TOLEDO, V. M. El metabolismo social: una nueva teoría socioecológica. Relaciones, (136): 41-71; 2013.

TOMAZELLI, L.J. \& VILLWOCK, J.A. O Cenozóico do Rio Grande do Sul: geologia da planície costeira. In: Holz, M.; De Ros, L.F. (Eds.) Geologia do Rio Grande do Sul. Porto Alegre: Edições CIGO-UFRGS, 2000. pp.375-406.

ZARTH, P. A; GERHARDT, M. Uma história ambiental do Pampa do Rio Grande do Sul. In: TEIXEIRA FILHO, A (org.). Lavouras da destruição: a (im)posição do consenso. Pelotas: UFPEL; 2009. p.249-295. 